\title{
Characteristics of Fructose-1,6-bisphosphatase from the Methanol-utilizing Yeast Hansenula polymorpha
}

\author{
By MARGARET M. ATTWOOD ${ }^{1 *}$ AND J. P. VAN DIJKEN ${ }^{2}$ \\ ${ }^{1}$ Department of Microbiology, The University, Sheffield S10 2TN, U.K. \\ ${ }^{2}$ Department of Microbiology, The University of Technology, Julianalaan 67A, 2628 BC Delft, \\ The Netherlands
}

(Received 12 January 1982)

\begin{abstract}
Fructose-1,6-bisphosphatase (EC 3.1.3.11) has been partially purified from methanol- and ethanol-grown Hansenula polymorpha. The enzyme was specific for fructose 1,6-bisphosphate as a substrate and did not react with sedoheptulose 1,7-bisphosphate. The enzyme purified from ethanol-grown cells resembled that from methanol-grown cells in all properties investigated, namely, temperature stability, substrate affinity, $\mathrm{pH}$-dependent inhibition by AMP, and $\mathrm{pH}-$ dependent stimulation of activity by EDTA. It is concluded that, although the metabolic role of fructose-1,6-bisphosphatase during growth on methanol and ethanol is completely different, growth on these substrates probably involves the same enzyme.
\end{abstract}

\section{INTRODUCTION}

As a result of enzymic, mutant and whole-cell studies, it has been established that growth of yeasts on methanol proceeds via the xylulose monophosphate (Xu5P) pathway of formaldehyde fixation (van Dijken et al., 1978; Babel \& Loffhagen, 1979; Kato et al., 1979; O'Connor \& Quayle, 1979; Waites \& Quayle, 1980; Lindley et al., 1980). The key reaction of this cycle (Fig. 1) is a transketolase type of condensation between xylulose 5-phosphate and formaldehyde, which results in the formation of $\mathrm{C}_{3}$ compounds (glyceraldehyde 3-phosphate and dihydroxyacetone). The rearrangement of these reaction products to xylulose 5-phosphate proceeds via fructose 1,6bisphosphate and fructose 6-phosphate. Therefore fructose-1,6-bisphosphatase (FBPase), which is present at enhanced levels during growth of yeasts on methanol (van Dijken et al., 1978), fulfils an essential role in methanol metabolism since the synthesis of all cell constituents proceeds via this reaction. In contrast when growth occurs on $\mathrm{C}_{2}, \mathrm{C}_{3}$ and $\mathrm{C}_{4}$ compounds the enzyme has a role in gluconeogenesis only. The Xu5P pathway of formaldehyde fixation is similar to the Calvin cycle. Thus during autotrophic fixation of $\mathrm{CO}_{2}, \mathrm{FBPase}$ has a similarly important role in the regeneration of the $\mathrm{C}$-5-acceptor molecule from the reaction products of the condensation, i.e. phosphoglycerate (Springgate \& Stathow, 1972; Joint et al., 1972; Abdelal \& Schlegel, 1974). It was, therefore, of interest to study the properties of the FBPase from a methylotrophic yeast, particularly since in some bacteria the FBPase functioning during autotrophic growth is reported to be different from that operating during growth on substrates that require gluconeogenesis (Amachi \& Bowien, 1979). The results reported in this communication indicate that the FBPase which is present in the yeast Hansenula polymorpha during growth on methanol is very similar in its properties to that present in ethanol-grown cells and resembles the enzyme commonly encountered in non-methylotrophic yeasts.

\section{METHODS}

Organism and growth. Hansenula polymorpha (CBS 4732) was grown in shake flasks on a mineral medium containing $0.5 \%(\mathrm{v} / \mathrm{v})$ methanol or ethanol as described previously (van Dijken et al., 1978).

Preparation of extracts. Cell-free extracts were prepared by ultrasonication (MSE model $150 \mathrm{~W}$ ) at $4{ }^{\circ} \mathrm{C}$ for $5 \times$ $1 \mathrm{~min}$ in $4 \mathrm{vol} 100 \mathrm{mM}-\mathrm{KH}_{2} \mathrm{PO}_{4} / \mathrm{NaOH}$ buffer $\mathrm{pH} 7.5$ containing $5 \mathrm{mM}-\mathrm{MgCl}_{2}$, in the presence of glass beads. 
Preparations were centrifuged at $18000 \mathrm{~g}$ for $20 \mathrm{~min}$ at $4{ }^{\circ} \mathrm{C}$ and the supernatants used as the cell-free extract.

Partial purification of FBPase. Crude cell-free extracts were brought to $\mathrm{pH} 5.5$ by the slow addition of $0.3 \%(\mathrm{v} / \mathrm{v})$ acetic acid; centrifuged $\left(18000 \mathrm{~g}, 20 \mathrm{~min}, 4^{\circ} \mathrm{C}\right)$ and the supernatant brought to $\mathrm{pH} 7.5$ by the addition of $1 \mathrm{M}-$ $\mathrm{KOH}$. The supernatant was taken to $50 \%$ saturation with $\left(\mathrm{NH}_{4}\right)_{2} \mathrm{SO}_{4}$ by the slow addition of solid $\left(\mathrm{NH}_{4}\right)_{2} \mathrm{SO}_{4}$ at $4{ }^{\circ} \mathrm{C}$. The $\mathrm{pH}$ was adjusted to 7.5 with $\mathrm{NH}_{4} \mathrm{OH}$ and desalted with a Sephadex G-25 column $(40 \times 2.5 \mathrm{~cm})$ equilibrated with $20 \mathrm{~mm}-\mathrm{KH}_{2} \mathrm{PO}_{4} / \mathrm{NaOH}$ buffer $\mathrm{pH} 7 \cdot 5$. The pooled active fractions were applied directly to a column $(7.5 \times 2 \mathrm{~cm})$ of hydroxylapatite (Bio-rad) which had been equilibrated with the same buffer. After the sample had been washed on to the column with $80 \mathrm{ml}$ of this buffer it was eluted with a linear phosphate gradient (20-500 mM made up in $500 \mathrm{ml}$ of the same buffer). Active fractions were pooled and concentrated using an Amicon ultrafiltration unit fitted with a PM10 Diaflo membrane (Amicon) to a concentration of $10 \mathrm{units}^{-1}$. The preparation was stored at $-20^{\circ} \mathrm{C}$. When the discontinuous assay, measuring the release of inorganic phosphate, was used, the Amicon filter preparation was added to the top of a Sephadex G-25 column $(20 \times$ $1.5 \mathrm{~cm}$ ) equilibrated in and eluted with $50 \mathrm{~mm}$-Tris $/ \mathrm{HCl}$ buffer $\mathrm{pH} 7.5$.

Enzyme assays. All w.1zyme assays were carried out at $37^{\circ} \mathrm{C}$ in a Pye-Unicam SP1800 double-beam recording spectrophotometer.

Unless stated otherwise FBPase (EC 3.1.3.11) was assayed by determining the rate of fructose 6-phosphate formation. The reaction mixture contained, in a final volume $1 \mathrm{ml}$ : Tris $/ \mathrm{HCl}$ buffer $\mathrm{pH} 8.5,100 \mathrm{mM} ; \mathrm{MgCl}_{2}$, $5 \mathrm{~mm}$; EDTA, $1 \mathrm{~mm}$; NADP, 0.4 mM; glucose-6-phosphate isomerase (EC 5.3.1.9), 1 unit; glucose-6-phosphate dehydrogenase (EC 1 1 1.1.49), 1 unit. The reaction was started by the addition of fructose 1,6-bisphosphate, $2 \mathrm{mM}$. When the effect of various inhibitors on the enzyme was investigated the compounds were pre-incubated for $5 \mathrm{~min}$ at $37^{\circ} \mathrm{C}$ in the assay mixture and the reaction started by the addition of fructose 1,6-bisphosphate.

For the determination of the substrate specificity of the enzyme the rate of inorganic phosphate release was measured. The reaction mixture was the same as that described for the spectrophotometric assay without the linkage enzymes. The inorganic phosphate released was determined by the method of Ames (1966).

Fructose-bisphosphate aldolase (EC 4.1.2.13) was assayed according to van Dijken et al. (1978).

Specific activities are expressed as units (mg protein $)^{-1}$. One unit is defined as $1 \mu$ mol substrate consumed or product formed $\min ^{-1}$.

Analytical methods and chemicals. Protein was estimated by the Lowry method using bovine serum albumin as standard. Biochemicals and enzymes were supplied by Boehringer.

\section{RESULTS AND DISCUSSION}

FBPase was purified 13-fold from methanol-grown $H$. polymorpha with a recovery of $40 \%$. The final preparation had a specific activity of 10.3 units (mg protein $)^{-1}$ and contained some FBP aldolase activity $\left.[0.15 \text { units (mg protein })^{-1}\right]$. However, under the conditions of the FBPase assay the aldolase activity was zero. This enabled an estimation of the $K_{\mathrm{m}}$ of the FBPase for fructose 1,6-bisphosphate to be obtained. Published procedures for the purification of this enzyme from Candida utilis (Rosen et al., 1965) such as heat treatment and precipitation with $\left(\mathrm{NH}_{4}\right)_{2} \mathrm{SO}_{4}$ at high saturation values could not be used since they resulted in an irreversible loss of enzyme activity. Attempts to purify the enzyme by gel filtration gave inconsistent results, probably due to the dissociation of the enzyme into subunits.

The enzyme preparation was rather unstable, having a half life of 1 week at $-20^{\circ} \mathrm{C}, 1 \mathrm{~h}$ at $30^{\circ} \mathrm{C}$, and $5 \mathrm{~min}$ at $37^{\circ} \mathrm{C}$. This instability is not uncommon in FBPases from yeast. The stability of the enzyme appears to relate to the species of yeast from which the enzyme has been purified. The enzyme from Saccharomyces cerevisiae was stable at $4{ }^{\circ} \mathrm{C}$, whereas in extracts of Pichia vini and Rhodotorula gracilis the half life of the enzyme was 1 and $3 \mathrm{~h}$, respectively, when stored at the same temperature (Gancedo \& Gancedo, 1971). The optimum pH for activity was 8.5 when assayed with the standard procedure. The enzyme required magnesium for maximal activity. Manganese could substitute for magnesium with $50 \%$ efficiency. The chelating agent EDTA markedly stimulated the enzyme activity at neutral $\mathrm{pH}$ values but almost full enzyme activity was observed at high (alkaline) pH values in the absence of EDTA. This stimulating effect of EDTA was more pronounced when the enzyme was in Tris/ $\mathrm{HCl}$ buffer rather than in glycine/ $\mathrm{NaOH}$ buffer, and may be due to the possible chelating effect of glycine in the latter buffer. When the enzyme activity was measured in the presence of a range of $\mathrm{Mg}^{2+}$ and EDTA concentrations the ratio of $\mathrm{Mg}^{2+}$ to EDTA in the reaction mixture was a more important parameter than the individual concentrations of $\mathrm{Mg}^{2+}$ or EDTA alone.

The enzyme was specific for fructose 1,6-bisphosphate as a substrate. Sedoheptulose 1,7- 


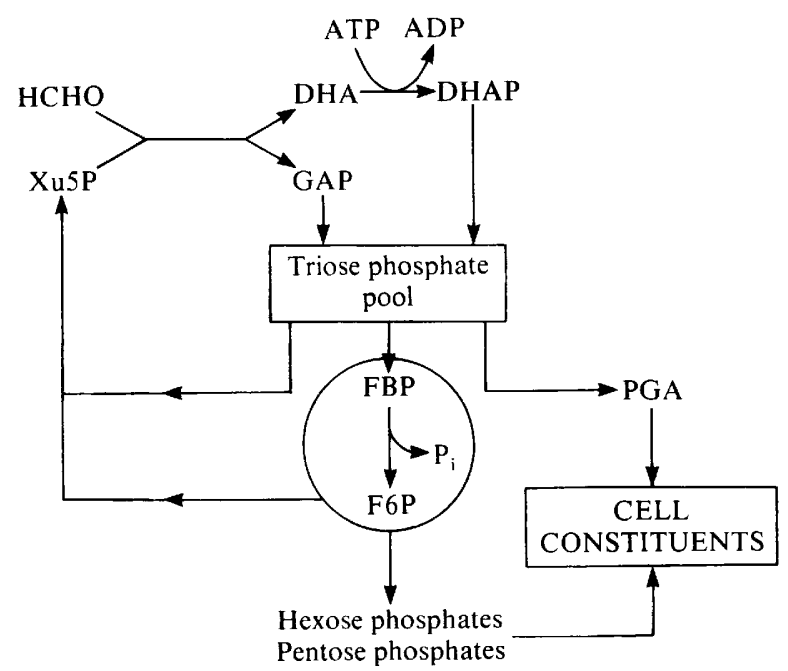

Fig. 1. The central role of FBPase in the formation of cell constituents via the xylulose phosphate pathway of formaldehyde fixation. Xu5P, xylulose 5-phosphate; DHA, dihydroxyacetone; DHAP, dihydroxyacetone phosphate; GAP, glyceraldehyde 3-phosphate; FBP, fructose 1,6-bisphosphate; F6P, fructose 6-phosphate; PGA, phosphoglycerate.

bisphosphate, ribose 5-phosphate, glucose 6-phosphate or fructose 1-phosphate were not substrates. The apparent $K_{\mathrm{m}}$ for fructose 1,6-bisphosphate was $2.9 \times 10^{-5} \mathrm{M}$.

A variety of compounds were tested as possible modulators of enzyme activity at concentrations between $0 \cdot 1$ and $2 \mathrm{~mm}$. Of those tested (ATP, ADP, AMP, GSH, CoA, xylulose 5phosphate, ribulose 5-phosphate, ribose 5-phosphate and dihydroxyacetone) only AMP had a significant effect on the enzyme. The inhibition exerted by AMP was dependent on the $\mathrm{pH}$ of the assay and decreased as the $\mathrm{pH}$ increased.

FBPase was also purified 45-fold from ethanol-grown cells of $H$. polymorpha with a recovery of $80 \%$. The final preparation had a specific activity of 9.6 units $(\mathrm{mg} \text { protein })^{-1}$. The properties of this preparation were essentially similar to that obtained from methanol-grown cells. It was labile, specific for fructose 1,6-bisphosphate as a substrate, with a $K_{\mathrm{m}}$ of $2 \cdot 2 \times 10^{-5} \mathrm{M}$, stimulated by EDTA at neutral $\mathrm{pH}$ values and inhibited by AMP.

Thus the FBPase from methanol- and ethanol-grown $H$. polymorpha is very similar, if not identical, and resembles the enzyme from C. utilis (Rosen et al., 1965). Unlike the situation in Nocardia opaca 1b (Amachi \& Bowien, 1979) and Thiobacillus A2 (Wood et al., 1977), in which different isoenzymes of FBPase are synthesized depending on the substrate for growth, in $H$. polymorpha it is probable that only one FBPase is synthesized irrespective of the growth substrate. Moreover, unlike FBPase from mammalian liver (Bonsignore et al., 1963), Rhodopseudomonas palustris (Springgate \& Stathow, 1972) and Hydrogenomonas eutropha (Abdelal \& Schlegel, 1974), but similar to the enzyme from C. utilis (Rosen et al., 1965) and Escherichia coli (Fraenkel et al., 1966), the $H$. polymorpha FBPase is specific for fructose 1,6-bisphosphate and does not react with sedoheptulose 1,7-bisphosphate. Since sedoheptulose bisphosphatase activity was also absent in crude cell-free extracts of methanol-grown $H$. polymorpha, it must be concluded that the enzyme is functioning as shown in Fig. 1 and does not play a role in a rearrangement reaction in which it functions as a sedoheptulose bisphosphatase in conjunction with a transketolase (see Zatman, 1981).

Apart from its substrate specificity, the FBPase purified from $H$. polymorpha resembles the FBPase from other micro-organisms (Springgate \& Stathow, 1972; Abdelal \& Schlegel 1974). Thus, it requires cations for activity $\left(\mathrm{Mg}^{2+}\right.$ or $\left.\mathrm{Mn}^{2+}\right)$, exhibits a $\mathrm{pH}$ optimum in the alkaline range, and has a similar $K_{\mathrm{m}}$ for fructose bisphosphate. Furthermore, like most FBPases it is stimulated by chelating agents (EDTA) particularly at neutral $\mathrm{pH}$ values (Rosen et al., 1965; Mukkada \& Bell, 1977; Van Tol et al., 1972; Nimmo \& Tipton, 1975; Pontremoli et al., 1979). 
An important aspect of the regulatory properties of FBPase is the significance of the in vitro regulation and its activity by AMP. FBPases purified from mammalian sources and heterotrophic bacteria are inhibited by AMP (Taketa \& Pogell, 1965; Opheim \& Bernlohr, 1975) whereas the FBPases from plant chloroplasts (Buchanan et al., 1971) and photolithoautotrophic and chemolithoautotrophic bacteria are insensitive to AMP but inhibited by ATP (Joint et al., 1972; Springgate \& Stathow, 1972; Abdelal \& Schlegel, 1974). The physiological rationale for AMP inhibition of FBPases in animals and heterotrophic bacteria grown on $\mathrm{C}_{2}, \mathrm{C}_{3}$ and $\mathrm{C}_{4}$ compounds is in the control of gluconeogenesis, since if FBPase is inhibited by AMP and not ATP the cell would be protected against a wasteful dephosphorylation of fructose 1,6-bisphosphate during active glycolysis (see review by Pontremoli \& Horecker, 1971). However, for two reasons, it is doubtful whether the in vitro inhibition of FBPase by AMP plays any regulatory role in vivo during growth of $H$. polymorpha on methanol. First, the major function of the enzyme during growth on this substrate is the regeneration of the assimilation products to form xylulose 5phosphate for formaldehyde fixation (Fig. 1), and the formation of fructose 1,6-bisphosphate itself would be decreased in the cell under conditions of low energy charge, due to a decreased phosphorylation of dihydroxyacetone by triokinase. Secondly, any regulatory role for the FBPase during growth on methanol would be difficult to explain since the FBPase purified from ethanol-grown $H$. polymorpha resembled that purified from methanol-grown cells in all the properties investigated, even though during growth on ethanol the enzyme has a role in gluconeogenesis only.

\section{REFERENCES}

Abdelal, A. T. \& Schlegel, H. G. (1974). Purification and regulatory properties of fructose-1,6-diphosphatase from Hydrogenomonas eutropha. Journal of Bacteriology 120, 304-310.

AMACHI, T. \& BowIEN, B. (1979). Characterisation of two fructose bisphosphatase isoenzymes from the hydrogen bacterium Nocardia opaca 1b. Journal of General Microbiology 113, 347-356.

AMES, B. N. (1966). Assay of inorganic phosphate. Methods in Enzymology 8, 115-116.

Babel, W. \& LoffHagen, N. (1979). Assimilation of methanol by yeasts, a new approach. Zeitschrift für allgemeine Mikrobiologie 19, 299-302.

Bonsignore, A., Mangiarotti, G., Manglarotti, M. A., De Flora, A. \& Pontremoli, S. (1963). Cleavage of sedoheptulose 1,7-diphosphate by a purified rat liver diphosphatase. Journal of Biological Chemistry 238, 3151-3154.

Buchanan, B. B., SchürmanN, P. \& Kalberer, P. P. (1971). Ferredoxin activated fructose diphosphatase of spinach chloroplasts: resolution of the system properties of the alkaline fructose diphosphatase component, and physiological significance of the ferredoxin-linked activation. Journal of Biological Chemistry 246, 5952-5959.

Fraenkel, D. G., Pontremoli, S. \& Horecker, B. L. (1966). The specific fructose diphosphatase of Escherichia coli: properties and partial purification. Archives of Biochemistry and Biophysics 114, 4-12.

GancEDo, J. M. \& GANCEDO, C. (1971). Fructose-1,6diphosphatase, phosphofructokinase and glucose-6phosphate dehydrogenase from fermenting and nonfermenting yeasts. Archiv für Mikrobiologie 76, 132138.

JoInt, I. R., Morris, I. \& Fuller, R. C. (1972). Purification of a complex of alkaline fructose-1,6bisphosphatase and phosphoribulokinase from Rhodospirillium rubrum. Journal of Biological Chemistry 247, 4833-4838.

Kato, N., Nischizawa, T., Sakazawa, C., Tani, Y.\&
Yamada, H. (1979), Xylulose 5-phosphate dependent fixation of formaldehyde in methanol-utilizing yeast Kloeckera sp. no. 2201. Agricultural and Biological Chemistry 43, 2013-2015.

Lindley, N. D., Waites, M. J. \& Quayle, J. R. (1980). A modified pulse-labelling technique for the detection of early intermediates in microbial metabolism: detection of $\left[{ }^{14} \mathrm{C}\right]$ dihydroxyacetone during assimilation of $\left[{ }^{14} \mathrm{C}\right]$ methanol by Hansenula polymorpha. FEMS Microbiology Letters 8, 13-16.

MUKKADA, A. J. \& BELl, E. J. (1971). Partial purification and properties of the fructose-1,6-diphosphatase from Acinetobacter lwoffi. Archives of Biochemistry and Biophysics 142, 22-31.

Nimmo, H. G. \& TiPToN, K. F. (1975). The purification of fructose-1,6-diphosphatase from ox liver and its activation by ethylenediaminetetra-acetate. Biochemical Journal 145, 323-334.

O'Connor, M. L. \& QuaYle, J. R. (1979). Mutants of Hansenula polymorpha and Candida boidinii impaired in their ability to grow on methanol. Journal of General Microbiology 113, 203-206.

Opheim, D. J. \& Bernlohr, R. W. (1975). Purification and regulation of fructose-1,6-biphosphatase from Bacillus licheniformis. Journal of Biological Chemistry 250, 3024-3033.

Pontremoli, S. \& Horecker, B. L. (1971). Fructose1,6-diphosphatases. In The Enzymes, vol. 4, pp. 611646. Edited by P. D. Boyer. New York and London: Academic Press.

Pontremoli, S., Sparatore, B., Salamino, F., MelLONI, E. \& HORECKER, B. L. (1979). Binding of $\mathrm{Zn}^{2+}$ to rabbit muscle fructose-1,6-bisphosphatase and its effect on the catalytic properties. Archives of Biochemistry and Biophysics 194, 481-485.

Rosen, O. M., Rosen, S. M. \& Horecker, B. L. (1965). Purification and properties of a specific fructose-1,6diphosphatase from Candida utilis. Archives of Biochemistry and Biophysics 112, 411-420.

Springgate, C. F. \& Stathow, C. S. (1972). Fructose- 
1,6-diphosphatase from Rhodopseudomonas palustris. 1. Purification and Properties. Archives of Biochemistry and Biophysics 152, 1-12.

TakeTA, K. \& Pogell, B. M. (1965). Allosteric inhibition of rat liver fructose-1,5-diphosphatase by adenosine 5'-monophosphate. Journal of Biological Chemistry 240, 651-662.

VAN DiJken, J. P., Harder, W., Beardsmore, A. J. \& QuAYLE, J. R. (1978). Dihydroxyacetone: an intermediate in the assimilation of methanol by yeasts? FEMS Microbiology Letters 4, 97-102.

VaN TOL, A., Black, W. J. \& Horecker, B. L. (1972). Activation of rabbit muscle fructose diphosphatase by EDTA and the effect of divalent cations. Archives of Biochemistry and Biophysics 151, 591-596.
Waites, M. J. \& Quayle, J. R. (1980). Dihydroxyacetone: a product of xylulose 5-phosphate-dependent fixation of formaldehyde by methanol-grown Candida boidinii. Journal of General Microbiology 118, 321-327.

Wood, A. P., Kelly, D. P. \& Thurston, C. F. (1977). Simultaneous operation of three catabolic pathways in the metabolism of glucose by Thiobacillus A2. Archives of Microbiology 113, 265-274.

ZATMAN, L. J. (1981). A search for patterns in methylotrophic pathways. In Microbial Growth on $C_{1} \mathrm{Com}$ pounds, pp. 42-53. Edited by H. Dalton. London: Heyden Press. 